\title{
Performance of Toria (Brassica campestrisvar. toria) on sulphur nutrition and soil test based nutrient management practice in farmers' field of West-Bengal Himalayan range
}

\author{
Tapas Kumar Pandit* \\ Regional Research Station (Old Alluvial Zone), Uttar Banga Krishi Viswavidyalaya, \\ Majhian, Dakshin Dinajpur-733133 (West Bengal), India \\ Saikat Mookherjee \\ Regional Research Station (Old Alluvial Zone), Uttar Banga Krishi Viswavidyalaya, \\ Majhian, Dakshin Dinajpur-733133 (West Bengal), India \\ Tapas Kumar Hembram \\ Regional Research Station (Old Alluvial Zone), Uttar Banga Krishi Viswavidyalaya, \\ Majhian, Dakshin Dinajpur-733133 (West Bengal), India \\ Jyotirmay Karforma \\ Regional Research Station (Old Alluvial Zone), Uttar Banga Krishi Viswavidyalaya, \\ Majhian, Dakshin Dinajpur-733133 (West Bengal), India \\ *Corresponding author. E-mail: tapas_pandit@rediffmail.com
}

\begin{abstract}
An on-farm trial was conducted in the farmers' field during 2013-14 and 2014-15 to assess the technology of application of sulphur on Toria (Brassica campestrisvar. toria)along with soil test based nutrient management practice under rain-fed condition at brown forest soil of the Himalayan range of West Bengal. The experiment was conducted at the seven villages namely Bong Busty, Charkhol, Sangsey, Bungkulung, Sakyong, Pudung, Didabling of Kalimpong district at an altitude ranged between $1210 \mathrm{~m}$ to $1300 \mathrm{~m}$. Significantly higher values of no. of primary branches (9.78); no. of siliquaplant ${ }^{-1}(82.12)$; no. of seeds siliqua ${ }^{-1}(35.51)$ as well as seed yield (1023 kg ha-1) were recorded with soil test based nutrient management practice along with soil application of sulphur $(80 \%) @ 20 \mathrm{~kg} \mathrm{ha}^{-1}$ as basal compared to the farmers' practice. The soil application of sulphur and soil test based nutrient management practice also fetched higher return per rupee invested (1.61) compared to the other treatments. No remarkable change was observed in soil fertility status after two years of experimentation. As it was an adoptive trial with the participation of farmers, the necessity of soil test based nutrient management practice and application of sulphur have been well realized by the participating farmers.
\end{abstract}

Keywords: Brassica campestris, On farm trial, Sulphur, Soil test based nutrient management, Toria

\section{INTRODUCTION}

Sulphur is a very important nutrient for oilseeds as the sulphur plays an important role in formation of volatile di- and poly-sulphide compounds which help to increase the pungency of the vegetable oils (Tandon 1995). Sulphur also plays an important role in the formation of Sulphur containing amino acids like cysteine $(27 \%$ S), cysteine $(26 \%$ S) and methionine $(21 \% \mathrm{~S})$ which are building blocks in the protein synthesis. More than $99 \%$ of sulphur in rapeseed-mustard group is bound in proteins and glucose isolates(Schnug et al. 1990). Sulphur is a constituent of oil in oilseed crops and it also has a great role in formation of chlorophyll

\section{Article Info}

https://doi.org/

10.31018/jans.v11i3.2143

Received: July 8, 2019

Revised: August 11, 2019

Accepted: August 29, 2019

\section{How to Cite}

Pandit, T. K. (2019). Performance of Toria (Brassica campestrisvar. toria) on sulphur nutrition and soil test based nutrient management practice in farmers' field of WestBengal Himalayan range. Journal of Applied and Natural Science, 11(3): 657 - 660 https://doi.org/ 10.31018/jans.v11i3.2143 
productivity and oil content of Brassica campestris var. toria increased significantly in the red soil of Odisha in addition of sulphur from different sources viz; SSP, gypsum and elemental sulphur. On the other side, dumping of fertilizers by the farmers in the fields without knowing soil fertility status and nutrient requirement by crop causes adverse effects on soil and crop regarding both toxicity and deficiency either by excessive use or inadequate use (Ray et al., 2000). Managing the location specific variability in nutrient supply is a key strategy to overcome the current escalation in the price of fertilizer rates and crop nutrient demand (Dobermann and Cassman, 2002).

Toria (Brassica campestrisvar. toria) is one of the major short duration oilseed crop under rapeseedmustard group which are widely cultivated in the hilly areas of West Bengal at an altitude of 1200$1300 \mathrm{~m}$ because it matures early. But this crop facing declining seed yield as well as oil yield now a days. This might be due to application of suboptimal or non-judicious fertilizer to the toria crop. Soil test based nutrient management practice may be the option to increase yield of the toriacrop. Keeping these in view, this on-farm trial was undertaken in the farmers' field that is under real farm situation to study the performance of different methods of application of sulphuron toria in under soil test based nutrient management practice in rain-fed areas of brown forest soil in the hilly region of West Bengal.

\section{MATERIALS AND METHODS}

On farm trial is the testing of technology in the real farm situation. It is an adoptive trial which is conducted under the supervision of the scientist in the farmers' field. The uniqueness is the participation of the farmers in all stages of the trial. Fujisaka (1989) also used the tool for understanding the different concerns and contributions on research by the farmers and scientists in the technology transfer. This on-farm trial was conducted during the year 2013-14 and 2014-15 at the seven villages namely Bong Busty, Charkhol, Sangsey, Bungkulung, Sakyong, Pudung, Didablingof Kalimpong district involving one progressive farmer from each village. All the seven villages of Kalimpong district were selected at an altitude ranged between $1210 \mathrm{~m}$ to $1300 \mathrm{~m}$. Conventional practicein the adjacent plot of the farmersin a particular village was the control treatment $\left(T_{0}\right)$ in the on-farm trial, where non-judicious and imbalanced application of fertilizers mainly DAP with no application of sulphur were under consideration. Soil test based nutrient management practices $\left(\mathrm{N}-\mathrm{P}_{2} \mathrm{O}_{5}\right.$ $-\mathrm{K}_{2} \mathrm{O}$ ) along with foliar application of sulphurat 15 DAS and 30 DAS @ $2.5 \mathrm{~kg} \mathrm{ha}^{-1}$ and $5 \mathrm{~kg} \mathrm{ha}^{-1}$ respectively considered as Treatment-1( $\left.T_{1}\right)$; soil test based nutrient management practices $\left(\mathrm{N}-\mathrm{P}_{2} \mathrm{O}_{5}-\right.$ $\mathrm{K}_{2} \mathrm{O}$ ) along with soil application of sulphur $(80 \%)$ @ $20 \mathrm{~kg} \mathrm{ha}^{-1}$ as basal considered as Treatment-2 $\left(T_{2}\right)$ in the on-farm trial.Both the treatments were allocated to the same farmers in each village. All the critical inputs like seeds, fertilizers and sulphur were supplied to the farmers for conducting the trials. B-54, popularly known as Agrani is one of the most cultivated variety of toriawas used as the test variety in this on-farm trial. The seeds were sown @6.5 kg ha-1 during October25-31 and October23-28 in the year 2013-14 and 2014-15 respectively. The statistical analysis of the recorded data collected from the field was done using the statistical software MSTAT-C version 2.1 of Michigan State University, USA and significant differences between the treatments were compared with the critical difference at $\pm 5 \%$ probability by LSD. The representative soil sample from the farmers' field were collected from all the seven

Table 1. Initial soil fertility status of the seven villages of Kalimpong district.

\begin{tabular}{llllll}
\hline Name of the villages & $\mathbf{O C ~ ( \% )}$ & $\mathbf{p H}$ & Available N Kg ha $^{-1}$ & ${\text { Available } \mathbf{P}_{\mathbf{2}} \mathbf{O}_{\mathbf{5}} \mathbf{K g ~ h a}^{-1}}^{\text {Available }_{\mathbf{2}} \mathbf{O K g ~ h a}} \mathbf{K}^{-1}$ \\
\hline Bong Busty & 1.75 & 4.98 & 219.84 & 17.61 & 278.86 \\
Charkhol, & 1.89 & 5.07 & 256.23 & 46.27 & 275.56 \\
Sangsey & 1.86 & 5.04 & 275.61 & 31.26 & 300.15 \\
Bungkulung & 1.79 & 5.01 & 265.94 & 38.45 & 289.56 \\
Sakyong & 1.85 & 5.03 & 271.56 & 36.79 & 297.23 \\
Pudung & 1.96 & 5.00 & 283.42 & 40.28 & 292.61 \\
Didabling & 1.78 & 5.01 & 268.12 & 39.66 & 279.58 \\
Mean value & $\mathbf{1 . 8 4}$ & $\mathbf{5 . 0 2}$ & $\mathbf{2 6 2 . 9 6}$ & $\mathbf{3 5 . 7 6}$ & $\mathbf{2 8 7 . 6 5}$ \\
\hline
\end{tabular}

Table 2. Effect of soil test based nutrient management and application of sulpur on yield components and seed yield of Toria (Var. B-54).

\begin{tabular}{|c|c|c|c|c|c|}
\hline Treatments & $\begin{array}{l}\text { No. of primary } \\
\text { branch plant }^{-1}\end{array}$ & $\begin{array}{l}\text { No. of sili- } \\
\text { qua plant }^{-1}\end{array}$ & $\begin{array}{l}\text { No. of seeds } \\
\text { siliqua }^{-1}\end{array}$ & $\begin{array}{l}\text { Test } \\
\text { weight (g) }\end{array}$ & $\begin{array}{l}\text { Yield } \\
\left(\mathrm{kg} \mathrm{ha}^{-1}\right)\end{array}$ \\
\hline $\mathrm{T}_{0}$ - Farmers' practice & 7.81 & 65.29 & 21.76 & 3.343 & 741 \\
\hline $\begin{array}{l}\mathrm{T}_{1} \text {-Soil test based application of } \mathrm{N}, \mathrm{P}_{2} \mathrm{O}_{5} \\
\text { and } \mathrm{K}_{2} \mathrm{O}+\text { Foliar application of sulphur } \\
\text { at } 15 \text { and } 30 \text { DAS @ } 2.5 \text { and } 5 \mathrm{~kg} \mathrm{ha}^{-1}\end{array}$ & 8.34 & 72.81 & 32.63 & 3.432 & 921 \\
\hline $\begin{array}{l}\mathrm{T}_{2} \text {-Soil test based application of } \mathrm{N}, \mathrm{P}_{2} \mathrm{O}_{5} \\
\text { and } \mathrm{K}_{2} \mathrm{O}+\text { soil application of elemental } \\
\text { sulphur }(80 \%) @ 20 \mathrm{~kg} \mathrm{ha}^{-1}\end{array}$ & 9.78 & 82.12 & 35.51 & 3.489 & 1023 \\
\hline C.D $(P=0.5)$ & 1.58 & 6.28 & 8.26 & NS & 130.21 \\
\hline
\end{tabular}


villages and analyzed for ascertaining the available nutrients in soil at initial stage following the standard methods and the requirement of doses were calculated accordingly. Urea, DAP and MOP were the source of nutrients supplied to the toria crop as per the soil test values.

The prevailing cost of various inputs like seeds, fertilizers, sulphur, ploughing charges, labour etc. during the time of experimentation were considered for working out the cost of cultivation.Gross return was calculated as per the prevailing market price of the produce at the time of harvest of the crop. Net return was calculated for each treatment by deducting the cost of cultivation ha ${ }^{-1}$ from the gross income ha ${ }^{-1}$. The average of two years of all the parameters recorded in the seven villages were considered for tabulation. Return rupee ${ }^{-1}$ invested $\mathrm{ha}^{-1}$ was calculated using the following formula.

Return Rs. ${ }^{-1}$ invested $^{-1}=$ Gross return (Rs.ha $\left.{ }^{-1}\right) /$ Cost of cultivation (Rs.ha ${ }^{-1}$ )

\section{RESULTS AND DISCUSSION}

Perusal of the data (Table 2) revealed thatthe major yield attributing characters viz. Number of primary branches, number of siliqua plant ${ }^{-1}$, number of seeds siliqua ${ }^{-1}$ increased significantly in soil test based nutrient management practice along with soil application of sulphur compared to the Farmers' practice. The number of primary branches of toria was recorded to be 9.78 in soil test based nutrient management practice along with soil application of sulphur followed by 8.34 in the treatment where crop received soil test based nutrient management practice along with foliar application of sulphurand 7.81 in farmers' practice. The number of siliqua plant ${ }^{-1}$ and number of seeds siliqua
${ }^{1}$ are also important yield attributing features of toria. The higher values of number of siliqua plant ${ }^{-1}$ (82.12) and number of seeds siliqua ${ }^{-1}$ (35.51) were also recorded where crop received nutrient management practices $\left(\mathrm{N}: \mathrm{P}_{2} \mathrm{O}_{5}: \mathrm{K}_{2} \mathrm{O}\right)$ as per the soil test value and soil application of sulphur @ $20 \mathrm{~kg}$ $\mathrm{ha}^{-1}$ compared two other two treatments. It was also revealed that the seed yield was significantly higher with the treatment comprising soil test based nutrient management practice along with soil application of sulphur @ $20 \mathrm{~kg} \mathrm{ha}^{-1}(1023 \mathrm{~kg} \mathrm{ha}$ $\left.{ }^{-1}\right)$ compared to the farmers' practice $\left(741 \mathrm{~kg} \mathrm{ha}^{-1}\right)$. On an average there was a yield increment of $38.06 \%$ over the conventional farmers' practice. However, there was no significant effect of the treatments towards test weight (1000 seed weight) of toria. As far as the production economics is concerned, the highest average net return (Rs.10, 439 $\left.\mathrm{ha}^{-1}\right)$ as well as the highest return per rupee of investment (1.61) were recorded in practice with the soil test based nutrient management along with soil application of sulphur @ $20 \mathrm{~kg} \mathrm{ha}^{-1}$ in comparison to cultivation practice of toria with soil test based nutrient management along with foliar spray of sulphur and farmers' practice (Table 3 ). Though the cost of cultivation was higher with the treatment comprising soil test based nutrient management along with soil application of sulphur but due to higher productivity of toria with this treatment fetched highest net return as well as return rupee ${ }^{-1}$ invested. After two years of experimentation no remarkable change has been observed in residual soil fertility status (Table 4).

The effect of soil test based nutrient management and soil application of sulphur was more pronounced on the yield attributing characters of toria. As sulphur improves the vegetative structure for nutrient absorption and provides strong sink

Table 3. Effect of soil test based nutrient management and application of sulpur on production economics of toria (Var. B-54).

\begin{tabular}{lllll}
\hline Treatments & $\begin{array}{l}\text { Cost of cultiva- } \\
\text { tion }\left(\text { Rs.ha }^{-1}\right)\end{array}$ & $\begin{array}{l}\text { Gross return } \\
\left(\text { Rs ha }^{-1}\right)\end{array}$ & $\begin{array}{l}\text { Net return } \\
\left(\text { Rs.ha }^{-1}\right)\end{array}$ & $\begin{array}{l}\text { Return per rupee } \\
\text { of investment }\end{array}$ \\
\hline $\mathrm{T}_{0}$ - Farmers' practice & 16450 & 20059 & 3609 & 1.22 \\
$\mathrm{~T}_{1}$-Soil test based application of $\mathrm{N}, \mathrm{P}_{2} \mathrm{O}_{5}$ & 16698 & 24843 & 8145 & 1.49 \\
$\begin{array}{l}\text { and } \mathrm{K}_{2} \mathrm{O}+\text { Foliar application of sulphur at } \\
15 \text { and 30 DAS @ 2.5 and 5 kg ha }\end{array}$ & & & & \\
$\mathrm{T}_{2}$-Soil test based application of $\mathrm{N}, \mathrm{P}_{2} \mathrm{O}_{5}$ & 17123 & 27562 & 10439 & 1.61 \\
$\begin{array}{l}\text { and } \mathrm{K}_{2} \mathrm{O}+\text { soil application of elemental } \\
\text { sulphur }(80 \%) \text { @ 20 } \mathrm{kg} \mathrm{ha}^{-1}\end{array}$ & & & & \\
\hline
\end{tabular}

Table 4. Residual soil fertility status after two years of experimentation (Mean values of soils of seven villages).

\begin{tabular}{|c|c|c|c|c|c|}
\hline Treatments & OC (\%) & pH & $\begin{array}{l}\text { Available N } \\
\mathrm{Kg} \mathrm{ha}^{-1}\end{array}$ & $\begin{array}{l}\text { Available } \\
\mathrm{P}_{2} \mathrm{O}_{5} \mathrm{Kg} \mathrm{ha}^{-1}\end{array}$ & $\begin{array}{l}\text { Available } \\
\mathrm{K}_{2} \mathrm{OKg} \mathrm{ha}{ }^{-1}\end{array}$ \\
\hline $\mathrm{T}_{0}-$ Farmers' practice & 1.82 & 5.0 & 259.82 & 34.64 & 286.69 \\
\hline $\begin{array}{l}\mathrm{T}_{1} \text {-Soil test based application of } \mathrm{N}, \quad \mathrm{P}_{2} \mathrm{O}_{5} \\
\text { and } \mathrm{K}_{2} \mathrm{O}+\text { Foliar application of sulphur at } 15 \\
\text { and } 30 \text { DAS @ } 2.5 \text { and } 5 \mathrm{~kg} \mathrm{ha}^{-1}\end{array}$ & 1.85 & 5.03 & 263.02 & 37.24 & 289.12 \\
\hline $\begin{array}{l}\mathrm{T}_{2} \text {-Soil test based application of } \mathrm{N}, \mathrm{P}_{2} \mathrm{O}_{5} \\
\text { and } \mathrm{K}_{2} \mathrm{O}+\text { soil application of elemental } \\
\text { sulphur }(80 \%) @ 20 \mathrm{~kg} \mathrm{ha}^{-1}\end{array}$ & 1.86 & 5.02 & 264.18 & 36.89 & 291.06 \\
\hline
\end{tabular}


through the development of reproductive structure (Sharma and Singh, 2005), the soil application of sulphur in toria might have played a vital role in strengthening sink and boosting photosynthetic activities leading towards higher seed yield. Tomar et al., (1996), in a field grown mustard observed a significant higher seed yield in soil application of sulphur. This might be due to the higher uptake of sulphur by the crop on external application of sulphur. Jaiswal et al. (2015) also observed significantly higher uptake of sulphur by mustard crop with application of sulphur which was reflected in to the higher seed yield.

Soil test based fertilizer recommendation calibrated on the logic that nutrient requirement of the crop minus nutrient supplied by soil should be the fertilizer needed. Soil test based nutrient management of nitrogen, phosphorus and potassium might also had a great role in adequate supply to the toriacrop and subsequent uptake of the nutrients as well as enhanced yieldby the plant system. In a study Verma et al. (2017) also opined that soil test based fertilizer recommendations are more precise and meaningful. This practice is not only the scientific basis for balanced fertilization but it also enables farmer to choose the proper fertilizer management practices.

\section{Conclusion}

The soil test based nutrient management of nitrogen, phosphorus and potassium coupled with soil application of sulphur (80\%) @ 20 kg ha ${ }^{1}$ as basal might be a better option in enhancement in yield of toriain rain-fed areas at an altitude ranging $1210-1300 \mathrm{~m}$ of Himalayan range in West Bengal. This treatment combination may be recommended for large scale demonstration for toria crop as well as its adoption by the farmers of this region.

\section{REFERENCES}

1. Dobermann, A., Cassman, K.G. (2002). Plant nutrient management for enhanced productivity inintensivegrain production systems of the United States and Asia. Plant and Soil.247(1):153-175.

2. Fujisaka, S. (1989). A Method for Farmerparticipatory Research and Technology Transfer:
Upland Soil Conservation in the Philippines. Experimental Agriculture. 25(4): 423-433. DOI: 10.1017/ S0014479700015064

3. Jaiswal, A.D., Singh, S., Singh, Y.K., Singh, S.and Yadav, S.N. (2015). Effect of Sulphur and Boron on Yield and Quality of Mustard (Brassica juncea L.) Grown on Vindhyan Red Soil. Journal of the Indian Society of Soil Science. 63: 362. DOI 10.5958/09740228.2015.00047.X.

4. Marschner, H. (1986) Mineral Nutrition of Higher Plants.Academic Press Inc., London, UK.

5. Pasricha, N. S. Bahl, G. S., Aulakh, M. S., Dhillon, K. S. (1991). Fertiliser use research in oilseed and pulse crops in India. PubHc Inf. Div. (ICAR). New Delhi, 99.

6. Ray, P.K., Jana, A.K., Maitra, D.N, Saha, M.N., Chaudhury, J., Saha, S.(2000).Fertilizer prescriptions on soil test basis for jute, rice and wheat in TypicUstochrept. Journal of Indian Society of Soil Science. 48:79-84.

7. Saalbach, E. (1973). The effect of sulphur, magnesium and sodium on yield and quality ofagricultural crops. Pontificiae Acad. Sci. ScriptaVaria Nr.38: 541589.

8. Sahoo, G.C., Biswas, P.K. and Santra, G.H (2017).Effect of Different Sources of Sulphur on Growth, Productivity and Oil Content of Brassica campestris var. toria in the Red Soil of Odisha. International Journal of Agriculture, Environment and Biotechnology.10 (6): 689-694, DOI: 10.5958/2230732X.2017.00085.7

9. Schnug, E., Haneklaus, S. and Wathelet, J.P. (1990). Experienceswith the X-R $F$ Method for the determination of the total glucosinolate content in rapeseed. GCIRCBulletin6, 120-125.

10.Sharma, O.P. and Singh, G.D. (2005). Effect of sulphur in conjunction with growth substances on productivity of clusterbean (Cyamopsis tetragonoloba) and residual effect on barley. Indian Journal of Agronomy.50 (1):16-18.

11.Tandon, H.L.S. (1995) Sulphur in Indian agriculture update. Sulphur in Agriculture 19, 3-8.

12.Tomar, R. K. S., Chourasia, S. C, Raghu, J. S., Singh, V.B. (1996). Growth yield and net returns of mustard under different levels of nitrogen and sulphur application on clay loam soils. J. Oilseeds Res. 13(1): 13-17.

13.Verma, M., Singh, Y.V., Dey P. and Babu, A.(2017). Soil Test based Fertilizer Recommendation for Mustard (Brassica Juncea L.) in Eastern Plain Zone of Uttar Pradesh, India. International Journal of Current Microbiology and Applied Science, 6(2):155-161. DOI: http://dx.doi.org/10.20546/ijcmas.2017.602.022 